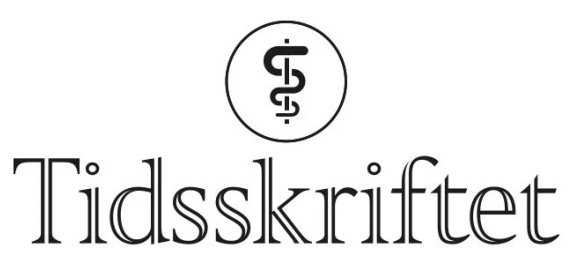

DEN NORSKE LEGEFORENING

\title{
Betydelig nedgang i kreftdiagnostikk under covid-19-pandemien
}

DEBATT

\section{SIRI LARØNNINGEN}

siri.laronningen@kreftregisteret.no

Siri Larønningen er cand.scient. og spesialrådgiver ved Registeravdelingen, Kreftregisteret. Forfatteren har fylt ut ICMJE-skjemaet og oppgir ingen interessekonflikter.

\section{ANNA SKOG}

Anna Skog er cand.scient. og rådgiver ved Registeravdelingen, Kreftregisteret. Forfatteren har fylt ut ICMJE-skjemaet og oppgir ingen interessekonflikter.

\section{JOHANNE GULBRANDSEN}

Johanne Gulbrandsen er MSHI og seksjonsleder ved Registeravdelingen, Kreftregisteret. Forfatteren har fylt ut ICMJE-skjemaet og oppgir ingen interessekonflikter.

\section{TOM BØRGE JOHANNESEN}

Tom Børge Johannesen er dr.med., overlege og nestleder ved Registeravdelingen, Kreftregisteret. Forfatteren har fylt ut ICMJE-skjemaet og oppgir ingen interessekonflikter.

\section{INGER KRISTIN LARSEN}

Inger Kristin Larsen er ph.d., forsker og seksjonsnestleder ved Registeravdelingen, Kreftregisteret. Forfatteren har fylt ut ICMJE-skjemaet og oppgir ingen interessekonflikter.

\section{$B J \varnothing R N M \varnothing L L E R$}

Bjørn Møller er ph.d., forsker og avdelingsleder ved Registeravdelingen, Kreftregisteret. Forfatteren har fylt ut ICMJE-skjemaet og oppgir ingen interessekonflikter.

\section{GISKE URSIN}

Giske Ursin er cand.med., ph.d. og direktør i Kreftregisteret.

Forfatteren har fylt ut ICMJE-skjemaet og oppgir ingen interessekonflikter.

\section{For flere kreftformer er det en markant nedgang i registrerte tilfeller under første del av covid-19-pandemien, viser en ny rapport fra Kreftregisteret.}


Siden januar 2020 har regjeringens, Helsedirektoratets og Legeforeningens overordnede prioriteringer ført til anbefalinger om å begrense planlagte inngrep og planlagte polikliniske konsultasjoner til et «absolutt nødvendig nivå»(1)-(3). Pasienter har i størst mulig grad blitt behandlet ved sitt lokalsykehus, og organiserte masseundersøkelser (screening) mot kreft ble stanset midlertidig en periode våren 2020. Fastlegene skulle fortsatt ivareta innbyggernes behov for legetjenester, både som følge av covid-19 og andre akutte og kroniske medisinske tilstander. Likevel medvirket sannsynligvis både forventede kapasitetsutfordringer, generell bekymring rundt smitte og sosial nedstenging til at terskelen for å oppsøke helsetjenesten for andre tilstander enn covid-19 var betraktelig høyere enn normalt.

\section{Hva er inkludert i rapporten?}

Kreftregisteret får tilsendt informasjon om kreft, forstadier til kreft og enkelte benigne svulster fra flere ulike kilder, blant annet patologiavdelinger, spesialisthelsetjenesten og andre nasjonale registre. Over 9o \% av alle krefttilfellene er morfologisk verifisert (4.), og patologisvarene utgjør derfor en viktig kilde til informasjon. Patologisvar sendes tilnærmet automatisk til Kreftregisteret.

\section{«Terskelen for å oppsøke helsetjenesten for andre tilstander enn covid-19 var sannsynligvis betraktelig høyere enn normalt»}

I Kreftregisterets nylig publiserte rapport er det kun tatt med krefttilfeller som er rapportert med patologisvar (5). Det betyr at krefttilfeller som utelukkende var klinisk diagnostisert, og hvor det aldri ble tatt noen vevsprøve, er utelatt. Dette skyldes at innrapporteringen fra klinikkene foreløpig ikke er komplett for den aktuelle tidsperioden. Resultatene i rapporten gir derfor ikke et fullstendig bilde på krefttilfellene for 2020. Resultatene skiller seg dessuten fra tall hentet fra Norsk pasientregister på grunn av ulik inkludering og ekskludering av diagnoser. Både type diagnose (kun maligne vs. alle diagnoser), behandlingssted (spesialisthelsetjenesten vs. hele helsetjenesten) og kilde (alle innleggelser vs. kun morfologisk verifiserte) bidrar til ulikheter. Ved å sammenligne antall patologisvar fra ett år til et annet kan vi imidlertid få et innblikk i de overordnede trendene og se om trendene for kreftdiagnostikk basert på patologisvar samsvarer med f.eks. trendene for kreftdata i Pasientregisteret.

Tilfellene i rapporten er talt opp på bakgrunn av første patologisvar per person (og per kreftform for de kreftspesifikke antallene) i perioden 2017-20. Patologiavdelingenes NORPAT/SNOMED-koder er brukt for å gruppere patologisvarene i ulike kreftformer.

\section{Markert nedgang i kreftdiagnostikken}

Analysene viser en markert nedgang i antall tilfeller av kreft, forstadier til kreft og enkelte benigne svulster i månedene etter mars 2020 sammenlignet med tilsvarende periode i 2019 (5). For de fleste kreftformer er nedgangen gjennomgående for hele perioden frem til september 2020, og størst for perioden mars-mai 2020. For de maligne tilfellene ser vi en total nedgang på 9,1\% i perioden mars-september, med en nedgang på 15,8 \% i perioden mars-mai. For alle diagnoser totalt (kreft, forstadier til kreft og enkelte benigne svulster) ser vi en nedgang på 12,7\% i perioden mars-september 2020 sammenlignet med samme periode i 2019. Nedgangen i perioden mars-mai var på hele $23 \%$.

Brystkreft (inkludert forstadier) og lungekreft hadde den største nedgangen i perioden mars-september, mens melanom, brystkreft (inkludert forstadier) og livmorhalskreft (inkludert forstadier) hadde den største nedgangen i perioden mars-mai. 
Basert på tidligere kreftstatistikk ventet vi en liten økning i antall tilfeller i 2020 sammenlignet med 2019, men resultatene tyder på at vi ikke kommer til å se denne $\emptyset$ kningen. Det er rimelig å anta at det er covid-19-pandemien og de tilhørende tiltakene som er hovedårsaken til nedgangen. Midlertidig stans av organiserte masseunders $\emptyset$ kelser (screening) mot kreft, omprioriteringer i helsetjenesten, høyere terskel for å oppsøke helsetjenesten - herunder frykt for smitte og ønske om ikke å belaste helsetjenesten «unødig» - samt mindre fokus på «diffuse» symptomer som ikke er knyttet til covid-19, har sannsynligvis alle medvirket til redusert kreftdiagnostikk. Når personer i mindre grad oppsøker helsetjenesten, reduseres også antallet svulster som påvises tilfeldig i forbindelse med utredning av og behandling for andre sykdommer og/eller skader.

\section{Hva blir langtidseffektene?}

Oppsummert medførte pandemien en nedgang i kreftdiagnostikken i perioden mars til september 2020. Hvordan kreftdiagnostikken blir i 2021, avhenger av hvor åpent eller lukket samfunnet blir denne våren. Det er rimelig å anta at situasjonen vi befinner oss $i$, vil påvirke både prioriteringene i helsetjenesten og den norske befolkningens terskel for å oppsøke helsetjenesten også i 2021.

\section{«Det er rimelig å anta at det er covid-19-pandemien og de tilhørende tiltakene som er hovedårsaken til nedgangen»}

Å predikere langtidseffektene er vanskelig. Det tar sannsynligvis flere år før vi vet om pasienter har fått kreften diagnostisert i et mer avansert/senere stadium som følge av pandemien, og hvilke konsekvenser dette har for overlevelse og behandlings-/oppfølgingsbehov i helsetjenesten. Kreftregisteret følger denne utviklingen tett fremover.

\section{LITTERATUR}

1. Regjeringen. Omfattende tiltak for å bekjempe koronaviruset. https://www.regjeringen.no/no/aktuelt/nye-tiltak/id2693327/ Lest 6.2.2021.

2. Helsedirektoratet. Prioritering av helsehjelp i Norge under covid-19-pandemien. https://www.helsedirektoratet.no/tema/beredskapogkrisehandtering/koronavirus/prioriteringsnotat-prioritering-av-helsehjelp-i-norgeunder-covid-19pandemien/spesialisthelsetjeneste\#somatisk-spesialisthelsetjeneste Lest 6.2.2021.

3. Legeforeningens råd om prioritering av pasienter under forløpet av en covid-19 epidemi. Oslo: Legeforeningen, 2020.

https://www.legeforeningen.no/contentassets/ao7c8c25f3d4463186odd6c9dc76bd61/legeforeningensrad-om-prioritering-av-pasienter-under-forlopet-av-en-covid-19-epidemi-per-16.4.20.pdf Lest 6.2.2021.

4. Cancer in Norway 2019-Cancer incidence, mortality, survival and prevalence in Norway. Oslo: Kreftregisteret, 2020. https://www.kreftregisteret.no/globalassets/cancer-in-norway/2018/cin2018.pdf Lest 6.2.2021.

5. Larønningen S, Skog A, Gulbrandsen J et al. Kreftdiagnostikk under Covid-19. Oslo: Kreftregisteret, 2021.https://www.kreftregisteret.no/koronarapporten Lest 6.2.2021.

Publisert: 9. februar 2021. Tidsskr Nor Legeforen. DOI: 10.4045/tidsskr.21.0068

Mottatt 25.1.2021, første revisjon innsendt 4.2.2021, godkjent 6.2.2021.

(C) Tidsskrift for Den norske legeforening 2023. Lastet ned fra tidsskriftet.no 26. april 2023. 